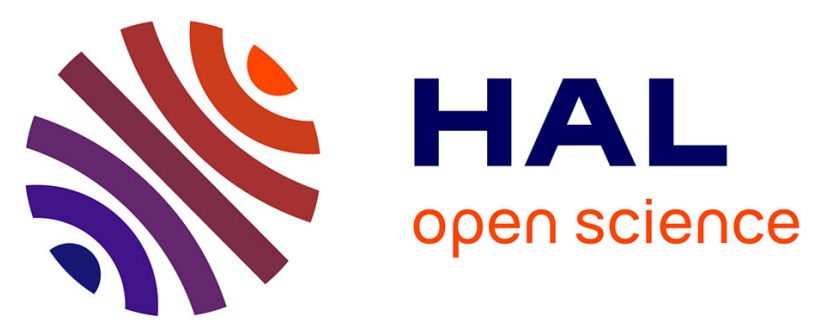

\title{
Large-scale aircraft observations of ultra-fine and fine particle concentrations in the remote Siberian troposphere: New particle formation studies
} Jean-Daniel Paris, Mikhail Yu. Arshinov, Philippe Ciais, Boris Belan, Philippe Nédélec

\section{To cite this version:}

Jean-Daniel Paris, Mikhail Yu. Arshinov, Philippe Ciais, Boris Belan, Philippe Nédélec. Largescale aircraft observations of ultra-fine and fine particle concentrations in the remote Siberian troposphere: New particle formation studies. Atmospheric environment, 2009, 43 (6), pp.1302-1309. 10.1016/j.atmosenv.2008.11.032 . hal-00519670

\section{HAL Id: hal-00519670 \\ https://hal.science/hal-00519670}

Submitted on 13 Jan 2022

HAL is a multi-disciplinary open access archive for the deposit and dissemination of scientific research documents, whether they are published or not. The documents may come from teaching and research institutions in France or abroad, or from public or private research centers.
L'archive ouverte pluridisciplinaire HAL, est destinée au dépôt et à la diffusion de documents scientifiques de niveau recherche, publiés ou non, émanant des établissements d'enseignement et de recherche français ou étrangers, des laboratoires publics ou privés.

\section{(c) (1) $\$$}

Distributed under a Creative Commons Attribution - NonCommerciall 4.0 International 


\title{
Large-scale aircraft observations of ultra-fine and fine particle concentrations in the remote Siberian troposphere: New particle formation studies
}

\author{
Jean-Daniel Paris ${ }^{\mathrm{a}, *}$, Mikhail Yu. Arshinov ${ }^{\mathrm{b}}$, Philippe Ciais ${ }^{\mathrm{a}}$, Boris D. Belan ${ }^{\mathrm{b}}$, Philippe Nédélec ${ }^{\mathrm{c}}$ \\ ${ }^{a}$ Laboratoire des Sciences du Climat et de l'Environnement/IPSL, CNRS-CEA-UVSQ, Orme des Merisiers, CEA Saclay, 91191 Gif sur Yvette, France \\ ${ }^{\mathrm{b}}$ Institute of Atmospheric Optics, SB-RAS, Tomsk, Russia \\ ${ }^{\mathrm{c}}$ Laboratoire d'Aérologie, CNRS-UPS, Toulouse, France
}

\begin{abstract}
Ultra-fine particle number concentrations were measured over Siberia during two large-scale airborne measurement campaigns in April and September 2006. During both campaigns, an aircraft flew between Novosibirsk and Yakutsk, collecting every $200 \mathrm{~km}$ vertical profiles up to $7 \mathrm{~km}$. This dataset was completed by 5 years of monthly profiles above Novosibirsk. Particle number concentration was measured in the size ranges 3-70 and 70-200 nm, along with other tracers. Free troposphere (FT) particle concentrations $\left(\mathrm{N}_{3-200}\right)$ varied between 60 and $460 \mathrm{~cm}^{-3}$, inferior to boundary layer concen-trations $\left(100-7000 \mathrm{~cm}^{-3}\right)$. In April, high concentrations of $\sim 500 \mathrm{~cm}^{-3}$ were observed in a polluted air mass recently uplifted at 5-6 km altitude over eastern Siberia, with no sign of significant new particle formation. In September, particle concentrations decreased with altitude, but with a steeper gradient in $\mathrm{N}_{70-200}$ compared to $\mathrm{N}_{3-70}$, the latter accounting for $90 \%$ of the total particle concentration in the free troposphere at 6-7 km altitude. Because ultra-fine particles presumably have short lifetimes, these observed particles could have been formed in situ in the clean Siberian atmosphere. Two cases of possible nucleation with high concentration and $\mathrm{N}_{3-70} / \mathrm{N}_{70-200}$ ratios are reported for the September campaign, in the upper troposphere and in cloud outflow in the mid-troposphere. In the seasonal analysis, a FT $\mathrm{N}_{3-70}$ maximum is found in July-August between 6 and $7 \mathrm{~km}$ altitude, with $\mathrm{N}_{3-70}$ accounting for $\sim 90 \%$ of $\mathrm{N}_{3-200}$ supporting the hypothesis of in situ formation in the FT. A secondary FT maximum of $\mathrm{N}_{3-70}$ was identified later in autumn. In the boundary layer, seasonally maximum $\mathrm{N}_{3-70}$ concentrations were found over Novosibirsk in May and September, but not in summer, possibly due to scavenging by precipitations and a large condensational sink from biomass burning aerosols. Our dataset has a limited size resolution and no speciation capability; more investigation is thus required to understand the conditions leading to in situ nucleation processes in the Siberian air shed.
\end{abstract}

\section{Introduction}

Aerosols play an essential role in the Earth system and impact the Earth energy balance due to their ability to interact with light and to nucleate clouds (Charlson et al., 1990). Free tropospheric particles are either uplifted from the boundary layer or formed in situ from gaseous precursors. Gas-to-particle conversion occurs as two competing processes: condensation on pre-existing particles or as nucleation. Binary homogeneous nucleation of sulphuric acid and water vapour is a dominant nucleation mechanism. High nucleation rates have also been observed at ultra-low sulphuric acid concentration (Covert et al., 1992, Hoppel et al., 1994; Weber

\footnotetext{
* Corresponding author. Tel.: +3316908 1700.

E-mail address: jean-daniel.paris@lsce.ipsl.fr (J.-D. Paris).
}

et al., 1996), suggesting ternary formation of new particles, e.g. with ammonia, is also a significant nucleation mechanism (Korhonen et al., 1999). Also, ion-induced nucleation (e.g. Lee et al., 2003) or activation of existing clusters (Kulmala et al., 2006a) can be important. Ultra-fine particles either grow or evaporate. Particles with size $\sim 10 \mathrm{~nm}$ have a lifetime of about $2 \mathrm{~h}$ in the free troposphere (Williams et al., 2002), increasing with decreasing condensational sink.

Freshly nucleated aerosols have been observed at many locations in the free troposphere (FT) (Covert et al., 1992; Weber et al., 1996; Clarke et al, 1998, 1999; Nyeki et al., 1999; de Reus et al. 2000; Twohy et al., 2002; Lee et al., 2003; Minikin et al., 2003; Young et al. 2007; Benson et al., 2008). Twohy et al. (2002) in particular observed high condensation nuclei concentration up to $45,000 \mathrm{~cm}^{-3}$ from nucleation in the outflow of a mesoscale convective system. These observations are summarized in Table 1. 
Table 1

Observed concentration distribution in the FT from the literature, mostly during nucleation events.

\begin{tabular}{|c|c|c|c|c|c|}
\hline Reference & $\begin{array}{l}\text { Concentrations } \\
\left(\mathrm{cm}^{-3}\right)\end{array}$ & $\begin{array}{l}\text { Size range } \\
(\mathrm{nm})\end{array}$ & Location & Latitude & Altitude \\
\hline $\begin{array}{l}\text { Schröder and } \\
\text { Ström, } 1997\end{array}$ & 50 & $7-18$ & $\begin{array}{l}\text { West } \\
\text { Europe }\end{array}$ & Mid lat & LT \\
\hline- & 300 & $7-18$ & - & - & UT \\
\hline- & 1500 & $>18$ & - & - & FT \\
\hline Nyeki et al., 1999 & {$[35-550]$} & $5-15$ & Germany & $46^{\circ} \mathrm{N}$ & FT \\
\hline- & [1000-2000] & $>15$ & - & - & - \\
\hline $\begin{array}{l}\text { De Reus et al., } \\
2000\end{array}$ & [50-100] & $6-18$ & Tenerife & $29^{\circ} \mathrm{N}$ & FT \\
\hline- & [500-1000] & $>18$ & - & - & - \\
\hline $\begin{array}{l}\text { Hermann et al., } \\
2003\end{array}$ & [50-500] & $4-12$ & Europe & Mid lat & UT/LS \\
\hline- & [1000-6000] & $>12$ & - & Mid lat & UT/LS \\
\hline $\begin{array}{l}\text { Minikin et al., } \\
2003\end{array}$ & $1400[450-15000]$ & $>5$ & $\mathrm{NH}$ & $\mathrm{NH}$ & UT \\
\hline- & 770 [290-9600] & $>14$ & - & - & - \\
\hline- & $40[16-90]$ & $100-1000$ & - & - & - \\
\hline $\begin{array}{l}\text { Twohy et al., } \\
2002\end{array}$ & Up to 45000 & $>25$ & $\begin{array}{l}\text { Central } \\
\text { US }\end{array}$ & Mid lat & UT \\
\hline Lee et al., $2003^{a}$ & 330 & $4-9$ & $\mathrm{NH}$ & $\begin{array}{l}\text { Mid \& high } \\
\text { lat }\end{array}$ & UT/LS \\
\hline${ }^{b}$ & 60 & $4-9$ & - & - & - \\
\hline- & $200-500$ & $4-2000$ & - & - & - \\
\hline $\begin{array}{l}\text { Young et al., } \\
2007^{c}\end{array}$ & $700-3960$ & 4-9 & US & Mid lat & UT/LS \\
\hline $\begin{array}{l}\text { Benson et al., } \\
2008^{\mathrm{a}}\end{array}$ & $200-400$ & $4-9$ & US & Mid lat & FT \\
\hline$-{ }^{\mathrm{a}}$ & $250-750$ & $4-2000$ & - & - & - \\
\hline This study $^{\mathrm{d}}$ & $50-350$ & $3-70$ & Siberia & Boreal & FT \\
\hline$-\mathrm{d}$ & $90-580$ & $3-200$ & - & - & - \\
\hline$-\mathrm{e}$ & $50-1100$ & $3-70$ & - & - & - \\
\hline$-{ }^{e}$ & $75-1500$ & $3-200$ & - & - & - \\
\hline
\end{tabular}

Range is given between square brackets.

a Average concentration reported in the presence of identified nucleation.

b Average concentration reported in the absence of identified nucleation.

c within tropopause fold.

d April 2006 campaign, all data.

e September 2006 campaign, all data.

Observations of nucleation in the clean continental free troposphere remain sparse. Leaitch and Isaac (1991) argued that continental FT surveys are likely to be affected by lateral advection of DMS-rich marine air.

No extensive study has been reported for the clean continental free tropospheric air shed of Siberia. Previous boundary layer studies in this region highlighted the contribution of anthropogenic and biogenic emission to aerosols concentrations (Bashurova et al. 1992; Koutsenogii et al. 1993; Koutsenogii, 1997; Vartiainen et al. 2007; Heintzenberg et al., 2008; Dal Maso et al., 2008). Most of Siberia exhibits deep atmospheric boundary layers in summer, as the relatively dry boreal conifer forests tend to produce high sensible heat fluxes (Baldocchi et al., 2000). The diurnal growth of a deep convective boundary layer will ensure vigorous ventilation of surface emissions such as biogenic volatile organic compounds (Lathiere et al., 2006) in summer, which may in turn favour nucleation (O'Dowd et al., 2002).

We present new aerosol size distribution data from two continent-wide campaigns carried out over Siberia (between $55^{\circ} \mathrm{N}$ and $63^{\circ} \mathrm{N}$ ) in September and April 2006 and from 5 years of monthly vertical profiles over Novosibirsk. The question of a nucleation signal in ultra-fine aerosols concentration in the Siberian FT, and its seasonal variation, is addressed.

Particle number concentrations are measured in the ranges 3$70 \mathrm{~nm}$ and $70-200 \mathrm{~nm}$. Ultra-fine particle number concentration in the 3-70 nm range ( $\mathrm{N}_{3-70}$ ) accounts for most of the total number of particles in remote clean continental air (Seinfeld and Pandis, 1998), but only for a negligible fraction of the aerosol mass. Particle

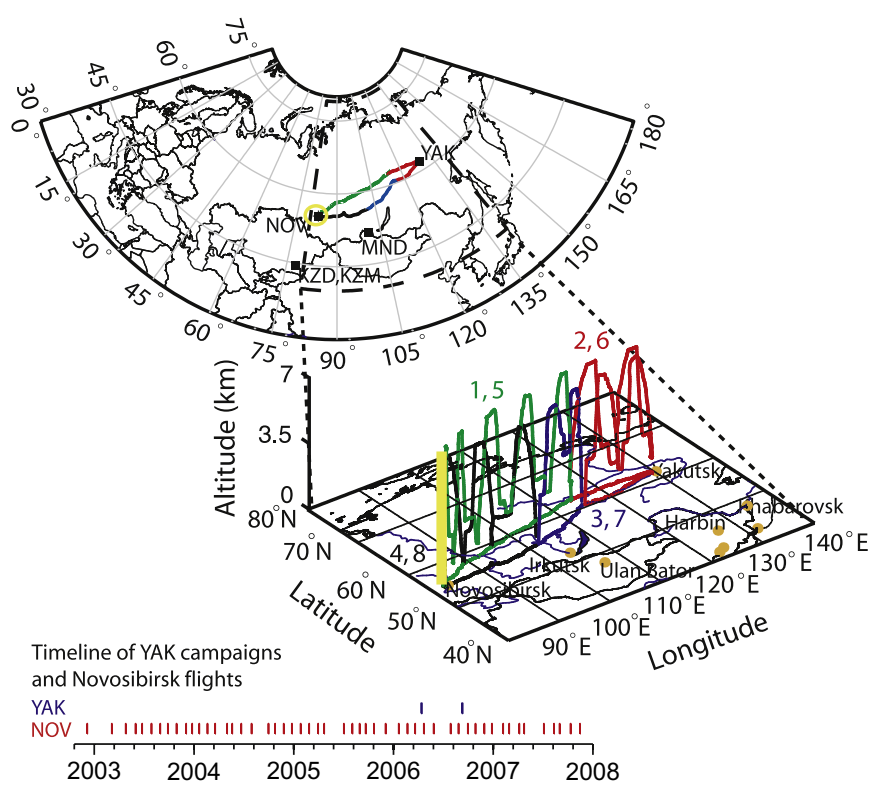

Fig. 1. Flight route during the campaigns. The April 2006 and September 2006 campaigns followed the same route. Each of these two campaigns was split into the same four flights (in the top panel, numbered 1 to 4 in April and 5 to 8 in September 2006 and differentiated by colours: green, red, blue and black). Novosibirsk profiles site is also shown in yellow. Bottom panel shows the timeline of measurements (red: regular profiles in Novosibirsk, blue: YAK intensive campaigns).

concentration in the $100-1000 \mathrm{~nm}$ size range is proportional to aerosol total surface and hence to the gaseous precursors aerosol surface sink. This coarse size resolution information is used to assess the large-scale distribution of ultra-fine particles in the free troposphere.

$\mathrm{CO}$ enhancement is used here as a tracer of pollution from anthropogenic sources and biomass burning. $\mathrm{SO}_{2}$ was not directly measured during our campaigns so we instead use $\mathrm{CO}$ as a proxy of potential gaseous precursors such as $\mathrm{SO}_{2}$. $\mathrm{CO}$ and $\mathrm{SO}_{2}$ have common anthropogenic sources, such as combustion of coal and other fuels, also emitting submicron particles of black carbon and organic carbon (e.g. Ohara et al., 2007). CO enhancements may not necessarily be correlated with enhancements in $\mathrm{SO}_{2}$ because of their different lifetimes against reaction with $\mathrm{OH}$ ( 1 month or more and a few days respectively; Seinfeld and Pandis, 1998).

\section{Methods}

The YAK-AEROSIB campaigns have been conducted in April and September 2006 (Paris et al., 2008) using a chartered Antonov-30 operated by the Institute of Atmospheric Optics in Tomsk. The two campaigns were carried so as to allow maximum sampling of the troposphere below $7 \mathrm{~km}$, with a see-saw flight pattern combining 26 vertical profiles between 0.5 and $7 \mathrm{~km}$ of altitude spaced horizontally by $\sim 300 \mathrm{~km}$ (Fig. 1). Each campaign consists of four flights, numbered 1-4 during the April campaign and 5-8 during the September campaign. Campaign measurements are completed by monthly vertical profiles near Novosibirsk (NOV in Fig. 1 top panel; Arshinov and Belan, 2004) collected between December 2002 and November 2007. The monthly flights use the same aerosol instrument and aircraft as the intensive campaigns. The NOV profiles were always collected between 1200 and 1600 local time, from the ground to $7 \mathrm{~km}$ altitude.

Ultra-fine particle concentration in the diameter range from 3 to $200 \mathrm{~nm}$ are measured using an 8-channel automated diffusion battery (ADB; designed by ICKC SB RAS, Novosibirsk; Reischl et al., 


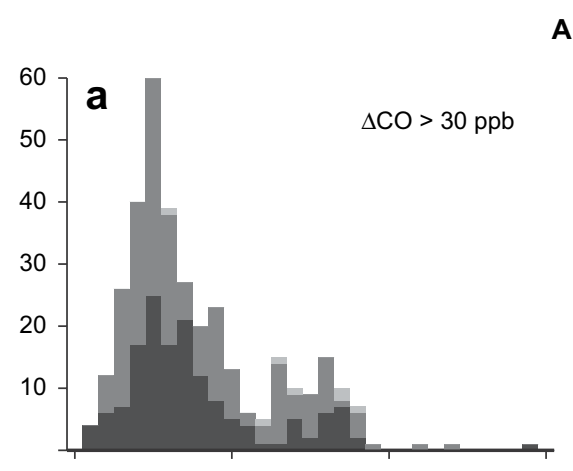

April 2006
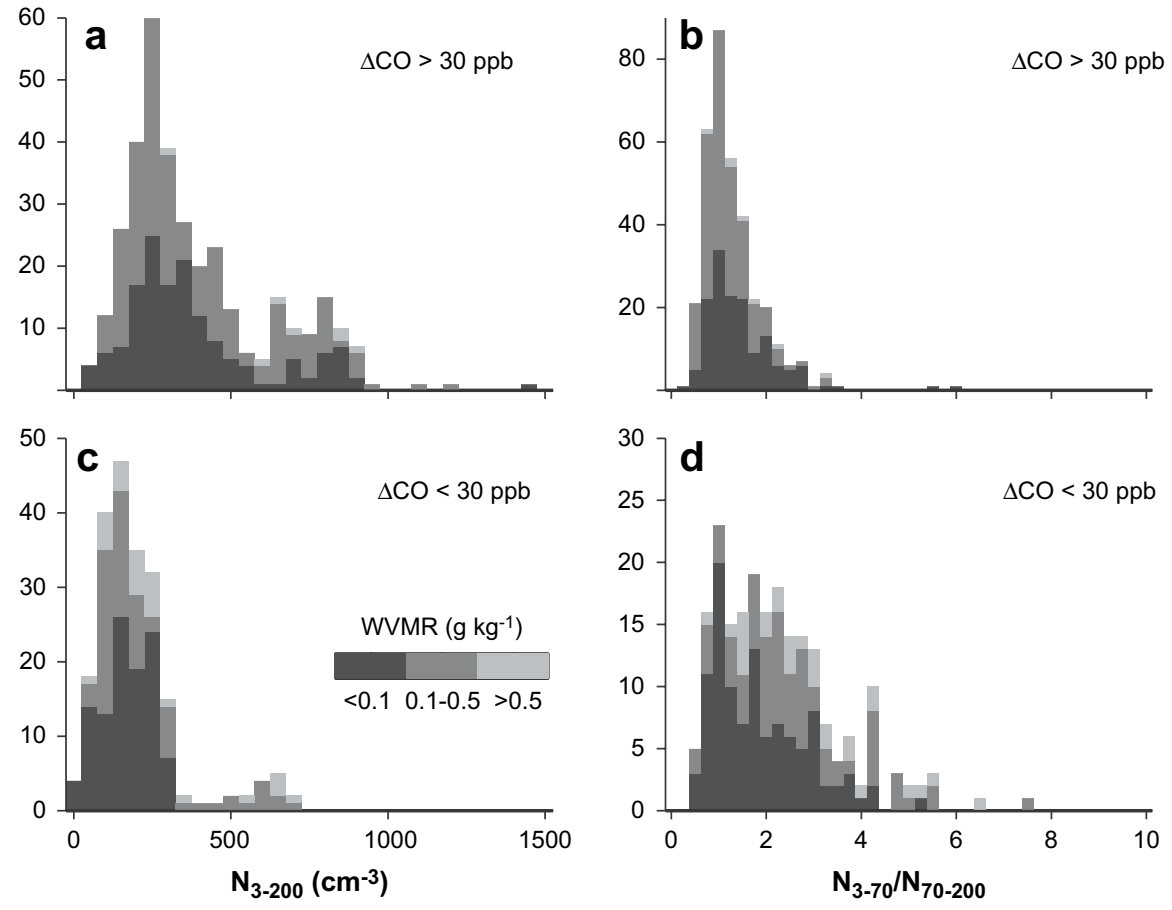

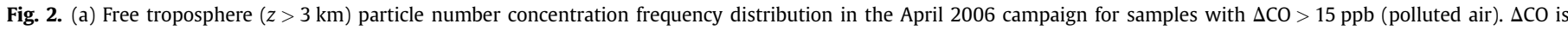

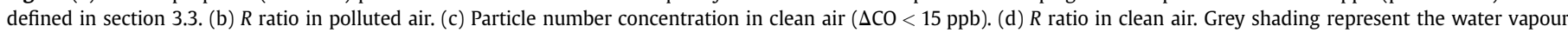
mixing ratio.

1991; Ankilov et al., 2002a, b) coupled to a condensation particle counter (Arshinov and Belan, 2004; Arshinov et al., 2007). Air is sampled using a quasi-isokinetic inlet (Zuev et al., 1992) at the front side of the aircraft. The ADB system has been specially designed for airborne applications with regulated flow rate, compensating for outside pressure variations and minimizing particle losses. In order to reduce integration (scanning) time and hence improve precision, only two channels of the battery are used in the instrument. This also improves the total particle concentration retrieval. Size response of the instrument is homogeneous over the $3-200 \mathrm{~nm}$ size range (Ankilov et al., 2002b) and for different aerosol compositions. Transmission efficiency for the airborne instrument is corrected for, and is $\sim 0.997$ in the $70-200 \mathrm{~nm}$ range and between 0.82 at $400 \mathrm{hPa}$ and 0.89 at $1000 \mathrm{hPa}$ for the $3-70 \mathrm{~nm}$ size range. All concentrations are reported at standard pressure and temperature (STP) conditions.

The CO airborne analyser used for the YAK-AEROSIB campaigns is described in Nedelec et al., 2003. It is an automated instrument modified from the commercial infrared absorption correlation gas analyser (Model 48C, Thermo Environment Instruments, USA) to reach an accuracy of $5 \mathrm{ppb}$ or $5 \%$ for $30 \mathrm{~s}$ integration time. Periodical (every $20 \mathrm{~min}$ ), in-flight accurate zero measurements were performed during the campaigns. The $\mathrm{O}_{3}$ instrument is derived from the commercial Thermo 49 instrument based on UV absorption with a precision of 2 ppb or $2 \%$ (e.g. Paris et al., 2008).

\section{Results and discussion}

\subsection{Particle concentrations during the intensive campaigns}

The total (sizes 3-200 nm) particle number concentration measured during the YAK-AEROSIB campaigns had a modal distribution of $150 \mathrm{~cm}^{-3}$. In the April 2006 campaign, the median concentration was $190 \mathrm{~cm}^{-3}$, and ranged from 90 to $580 \mathrm{~cm}^{-3}$ (10th and 90th percentile respectively; Fig. 2). One percent of the data exhibited concentrations higher than $10^{4} \mathrm{~cm}^{-3}$, mostly in the vicinity of airports (at take-off and landing). Above $3 \mathrm{~km}$, April concentrations are in the range $80-460 \mathrm{~cm}^{-3}$. The distribution of ultra-fine aerosols has a maximum in the boundary layer $(\mathrm{BL})$ where anthropogenic and biogenic emissions of aerosols and precursors are injected. In the lowest $1 \mathrm{~km}$, in a very stable and shallow boundary layer, the April concentration ranged between $10^{2}$ and $7 \times 10^{3} \mathrm{~cm}^{-3}$.

During the September 2006 campaign, the particle number concentrations observed were in the range $75-1.5 \times 10^{3} \mathrm{~cm}^{-3}$, (again, respectively 10th and 90th percentile; Fig. 3 ), with a median of $215 \mathrm{~cm}^{-3}$ and skewed towards lower concentrations. Above $3 \mathrm{~km}$, typical September concentrations are between 60 and $340 \mathrm{~cm}^{-3}$, and $1 \%$ of the data is above $3 \times 10^{3} \mathrm{~cm}^{-3}$. In the September BL (approximated by the lowest $2 \mathrm{~km}$ ), variability was less important than the lowest $1 \mathrm{~km}$ in April, with a range 350$2 \times 10^{3} \mathrm{~cm}^{-3}$.

Fig. 4 shows three examples of the distribution of particle number concentration in vertical profiles, each profile being averaged over a given flight $(6 \pm 2 \mathrm{~h})$. Also shown are the $\mathrm{CO}$ and water vapour mixing ratios. The September flights (shown in Fig. 4c; flight 8,10 September 2006) exhibit larger $\mathrm{N}_{3-200}$ value in the BL or immediately above the BL. The strong sensible heat flux from the forest mixes efficiently biogenic volatile organic compounds (VOC) emitted by the vegetation (O'Dowd et al., 2002; Lathière et al., 2006; Tarvainen et al., 2007) into deep convective BL (Baldocchi et al., 2000), lofting these compounds up to the entrainment zone, where they can reach into the FT by night (Stull, 1988). Conditions favourable to nucleation were met during the September campaign. No local, fresh biomass burning plume was observed at that time. Only one aged fire plume from (agricultural) biomass burning transported from Kazakhstan and the Caspian Sea area was measured, which exhibited the highest $\mathrm{CO}$ concentrations of the campaign. In the September data above $4 \mathrm{~km}$ altitude, $\mathrm{N}_{3-70}$ is 

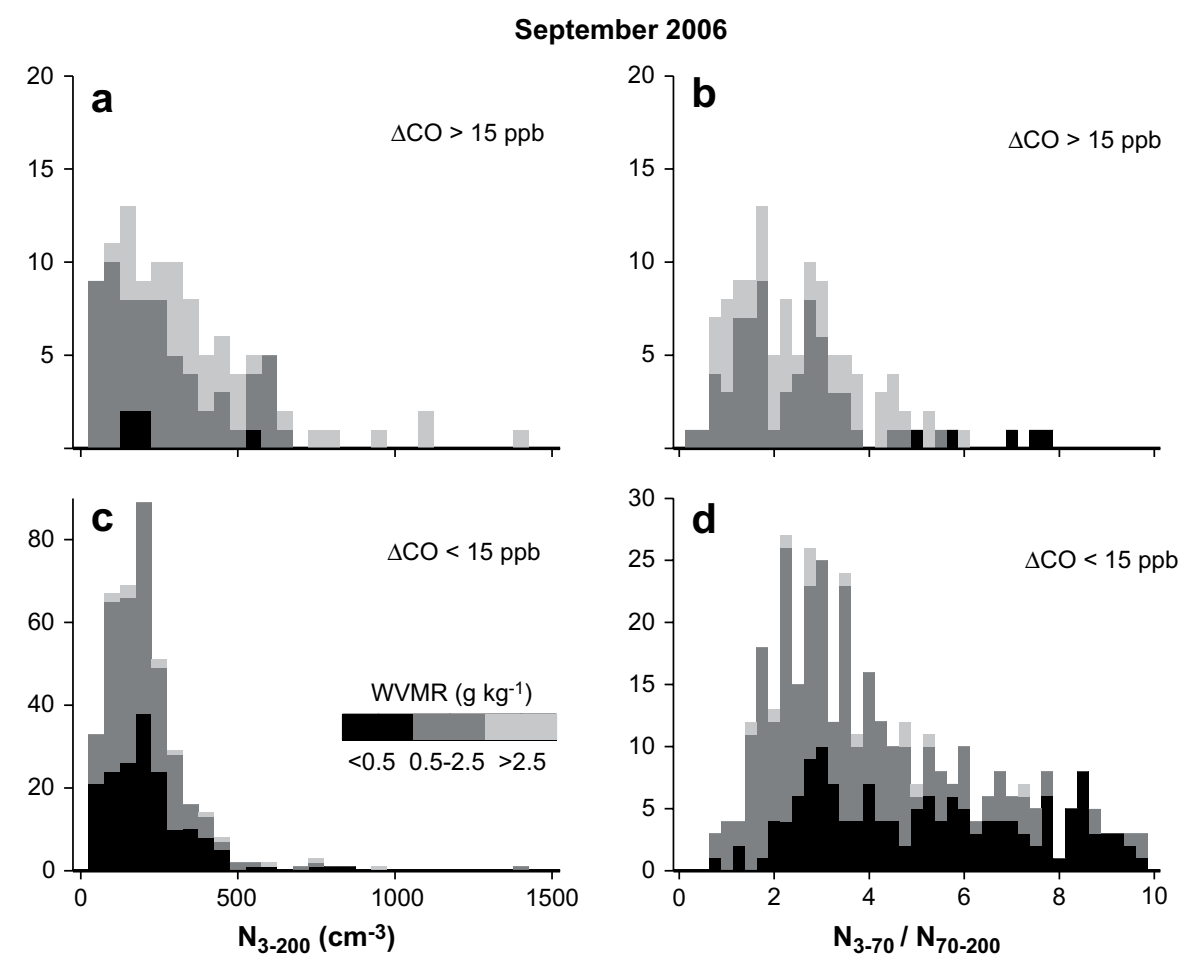

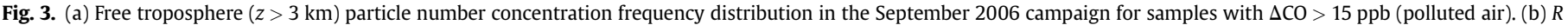
ratio in polluted air. (c) Particle number concentration in clean air ( $\Delta \mathrm{CO}<15 \mathrm{ppb}$ ). (d) $R$ ratio in clean air. Grey shading represent the water vapour mixing ratio.

higher by up to one order of magnitude than $\mathrm{N}_{70-200}$. On the contrary, the April flights (April 12, 2006, Fig. 4a) has concentrations of $\mathrm{N}_{3-70}$ and $\mathrm{N}_{70-200}$ particles approximately equal, from the ground to flight ceiling.

\subsection{Size distribution and the limitation of size resolution}

Here we rely on the relative concentration of particle in the two size ranges to discriminate fresh particles (roughly, nucleation and Aitken modes) from condensation nuclei (CN). In the troposphere, under specific conditions of humidity, temperature and incoming radiation, nucleation yields a larger number concentration of ultrafine particles relative to concentration nuclei. Studies on airborne aerosol measurements (using finer size resolution instruments) proposed nucleation event to be characterized by a modal distribution increased towards the finer sizes with specific criteria (see e.g. Covert et al., 1992; Lee et al., 2003; Young et al., 2007). We speculate here that a large increase in the ratio $R=\mathrm{N}_{3-70} / \mathrm{N}_{70-200}$ is sufficiently discriminative of freshly nucleated particles. The median of the $R$ value is 1.5 for the April campaign (see Fig. 2), and 2.5 for the September campaign (see Fig. 3). In the September 2006 campaign $20 \%$ of the data had $R>5$, and $5 \%$ had $R>10$. In the free troposphere above $4 \mathrm{~km}$ altitude, $65 \%$ of the data had $R>5$ and $10 \%$ had $R>10$. No more than $4 \%$ of the data reached $R>5$ in the April campaign. $11 \%$ of the September FT data had both $R>5$ and $\mathrm{N}_{3-}$ $70>100 \mathrm{~cm}^{-3}$, which can be considered a possible criteria for the assessment of recently nucleated particles in the FT. Only $2 \%$ of the April data responded to this criterion.

\subsection{Long range transport of surface tracers and particle concentrations: April 2006 case}

High particle concentrations coincided with $\mathrm{CO}$ enhancements (Figs. 2 and 4a) in the mostly dry April troposphere, irrespective of altitude. During flights 2 and 3 in April 2006 uplifted boundary layer air from polluted regions of China was identified in the midtroposphere in Siberia above $5 \mathrm{~km}$ by Paris et al. (2008). Elevated $\mathrm{CO}$ concentrations were observed in this uplifted pollution (Fig. 4a), alongside with an absence of $\mathrm{O}_{3}$ enhancement. The presence of Chinese pollution suggests the possible presence of coarse particles (anthropogenic and dust from dust storm in China), which could explain the absence of $\mathrm{O}_{3}$ enhancement. Additional gas to particle conversion may occur in this plume.

In our sampled air mass from China, the observed $\mathrm{N}_{3-200}$ had median $300 \mathrm{~cm}^{-3}$ and third quartile $\sim 500 \mathrm{~cm}^{-3}$, and was higher than in surrounding cleaner air (between 10 and $80 \mathrm{~cm}^{-3}$ ), but remained low, pointing to a condensational growth of existing aerosols. At $5 \mathrm{~km}$ altitude in the uplifted pollution plume, $\mathrm{N}_{3-70}$ was higher than $\mathrm{N}_{70-200}$, possibly reflecting a distinct layer where fresh nucleation occurred in the recent air mass history.

In the flights of April 2006, outside the well-defined uplifted pollution plume described above (which was encountered during Flights 2 and 3 ), the FT is characterized by very low $\mathrm{N}_{3-200}$ $\left(\sim 10^{2} \mathrm{~cm}^{-3}\right)$ even in polluted air masses with CO excess $(\Delta \mathrm{CO})$ of $\sim 100 \mathrm{ppb}$ (Fig. 5). $\Delta \mathrm{CO}$ is defined relative to the clean-air background according to Paris et al. (2008). There was no clear relation between $\Delta C O$ and the $R$ ratio in the April 2006 campaign dataset. Within the clean FT air masses, the $R$ ratio remained close to unity, suggesting a flat or symmetric size distribution. Over eastern Siberia (Flights 2 and 3), the $R$ ratio is $0.99 \pm 0.05$ in air masses having $\Delta \mathrm{CO}>50 \mathrm{ppb}$ (associated with Chinese pollution), whereas it is $1.28 \pm 0.11$ for surrounding air. This observation suggests that new particle formation must have been very limited in a recent history of the sampled air mass, possibly with preferential sink on pre-existing particles.

Using $\mathrm{CO}$ as a surface tracer suggests that this air mass was exposed to large concomitant sources of both $\mathrm{CO}$ and $\mathrm{SO}_{2}$ (Ohara et al., 2007). A literature survey suggests likely $\mathrm{CO} / \mathrm{SO}_{2}$ ratios in the outflow of NE Chinese boundary layer. During a Chinese pollution export event over Taiwan, Lin et al. (2007) show well correlated $\mathrm{SO}_{2}$ 

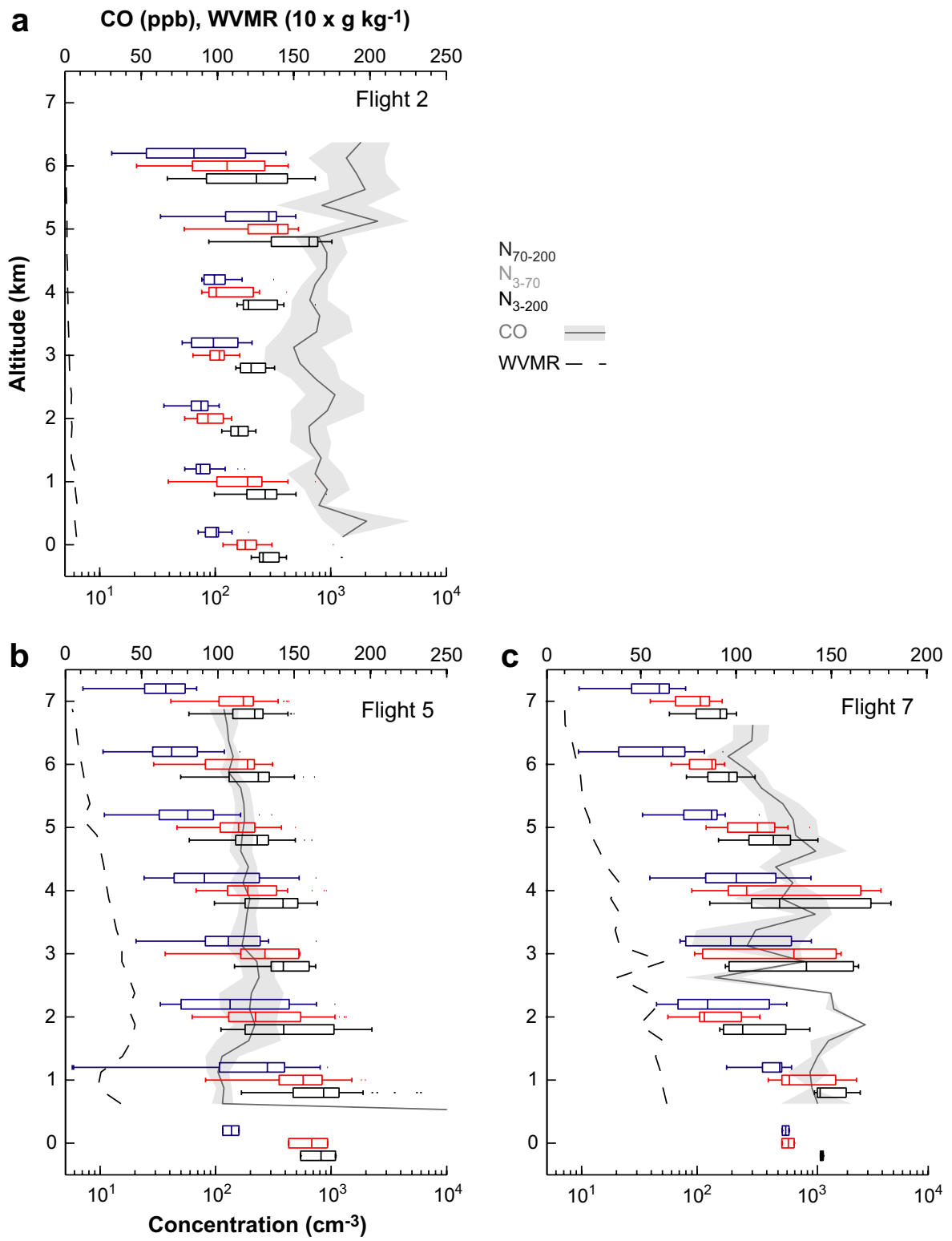

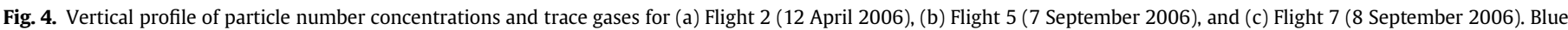

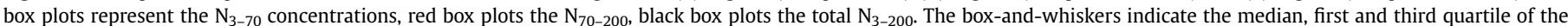

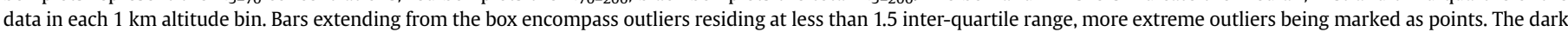

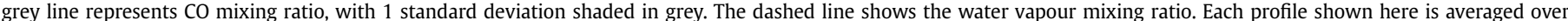
between 4 and 8 ascents and descents.

and $\mathrm{CO}$ measurement, with ratios of about $0.01-0.02 \mathrm{ppb}\left(\mathrm{SO}_{2}\right)$ / $\mathrm{ppb}(\mathrm{CO})$ after $\sim 1$ day of transport. By comparison, emission ratios from Ohara et al. (2007) are in the range $0.08-0.10 \mathrm{~mol}\left(\mathrm{SO}_{2}\right) /$ $\mathrm{mol}(\mathrm{CO})$. In the polluted air that we sampled in April 2006, the 50$60 \mathrm{ppb} \mathrm{CO}$ enhancements could therefore be translated into $\mathrm{SO}_{2}$ enhancements of about $0.5-1.2 \mathrm{ppb}$. In the immediate outflow of China in April Buzorius et al. (2004) found elevated CN concentration, coincident with high $\mathrm{SO}_{2}$ concentrations (10 ppb), and alternating with layers of high $\mathrm{CO}$ and coarser particles acting as condensational sink, similar to the Chinese outflow described above.

\subsection{Upper troposphere particle formation: September 2006 case}

In September 2006, increasing $R$ ratio was observed with decreasing CO enhancements (Figs. 3 and 4c). Dry FT air (4-8 km) has a lower concentration of particles but is characterized by $R$ ratio values up to 10. Due to a lower amount of anthropogenic pollution (for which we use $\Delta \mathrm{CO}$ as a proxy) in the Siberian air shed at that time, the formation of new particles is able to dominate over the condensational sink.

Fig. 5 shows measured particle concentrations as well as relative humidity, $\mathrm{CO}$ and $\mathrm{O}_{3}$ for Flight 5 on 7 September. Note the elevated CO concentrations ( $\Delta \mathrm{CO} \sim 60 \mathrm{ppb}$, with large $\mathrm{O}_{3}$ concentrations of 55-60 ppb) at about $2 \mathrm{~km}$ altitude at 0400-0415 UTC, resulting from the encounter with a biomass burning plume originating from Kazakhstan (Paris et al., 2008). The plume was encountered while crossing a warm front with heavy cloud cover (the cloud cover corresponding to the two sharp drops in particle concentration) The observed CO background in late summer is between 90 and $110 \mathrm{ppb}$, denoting a rather clean atmosphere. Particle concentrations are highly variable throughout the flight but two regimes emerge: high particle concentrations (a few thousand $\mathrm{cm}^{-3}$ ) in the 


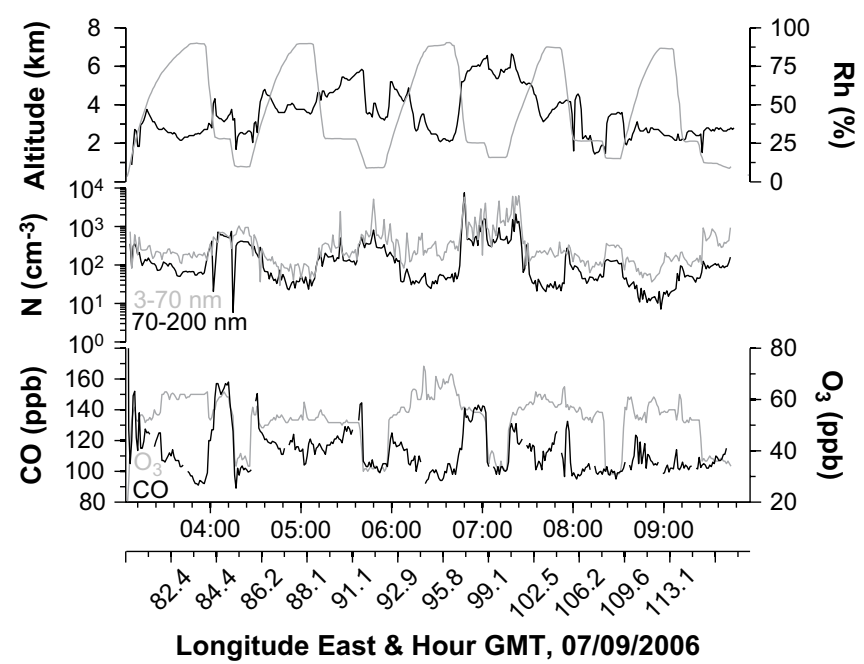

Fig. 5. Time series of relative humidity, altitude, and particle, $\mathrm{CO}$ and $\mathrm{O}_{3}$ concentrations for Flight 5 on 7 September 2006.

$\mathrm{BL}$ (identified by high humidity and very low $\mathrm{O}_{3}$ concentrations); and two occurrences (time between 0600 and 0800 ) of a stratospheric influence (marked by $\mathrm{O}_{3}$ concentrations up to $70 \mathrm{ppb}$ ) in the upper troposphere, where $\mathrm{N}_{3-70}$ is of the order of $100-200 \mathrm{~cm}^{-3}$ against $\mathrm{N}_{70-200}$ concentrations of $10-20 \mathrm{~cm}^{-3}$. This results in an $R$ ratio value of about 10 , denoting the influence of new particle formation. Surface tracer CO is very low during these cases, further confirming the isolation from surface sources and suggesting ioninduced or ion-mediated nucleation as a contribution to new particle formation (Lee et al., 2003). In order to test the possibility that we observe export of particles that have nucleated in the BL we have investigated the sensitivity of the $R$ ratio to surface emissions influence within a characteristic lifetime of $48 \mathrm{~h}$. Using the FLEXPART Lagrangian particle dispersion model (Stohl et al., 2005; Paris et al., 2008, results available online at http://zardoz.nilu.no/ $\sim$ andreas/YAK/) throughout the September 2006 campaign it was found that on average, in the air sampled above $4 \mathrm{~km}$, less than $1 \%$ of the sampled "air parcels" have resided in the lowest $300 \mathrm{~m}$ of the troposphere, and hence would have been possibly influenced by surface emissions within the last $48 \mathrm{~h}$. Due to their rather short lifetime, this rules out the vertical transport of particles originally nucleated in the BL to the FT. As a result our case study suggests that fresh particle nucleation occurred in the remote continental upper troposphere, with air well isolated from the BL. This could be attributed to the specific conditions (steep temperature and humidity gradients) in tropopause folds (Young et al., 2007).

\subsection{New particle formation in mid-tropospheric cloud outflow: September 2006 case}

The aircraft flew over convective clouds between 0750 and 0815 (Fig. 6) at $4 \mathrm{~km}$ altitude during Flight 7 (8 September 2006). The convection is reflected by a local increase in relative humidity to $\sim 80 \%$, and in CO concentrations to $\sim 150 \mathrm{ppb}$, about $50 \mathrm{ppb}$ above tropospheric background concentrations. Immediately past the outflow of the convection, concentrations of $\mathrm{N}_{3-70}$ increase by one order of magnitude up to $4000 \mathrm{~cm}^{-3}$ while $\mathrm{N}_{70-200}$ increases only up to $700 \mathrm{~cm}^{-3}$. As a result the $R$ ratio increased from unity at 0800 to about 6 . Ruling out size-dependent effects in aerosol load scavenging during convection, this strongly suggests the occurrence of new particle formation in the cloud outflow. According to FLEXPART up to $90 \%$ of the air parcels sampled with highest $R$ ratio values had resided in the $\mathrm{BL}$ in the last two days prior to sampling,

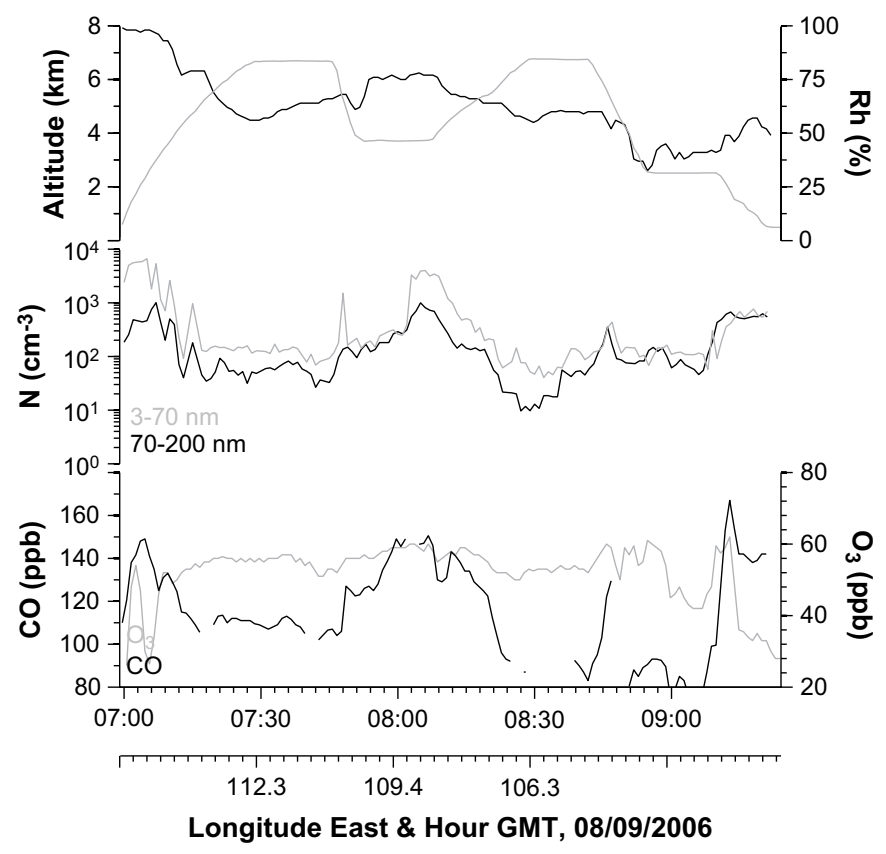

Fig. 6. Time series of relative humidity, altitude, and particle, $\mathrm{CO}$ and $\mathrm{O}_{3}$ concentrations for Flight 7 on 8 September 2006.

confirming the influence of uplifted BL air in the measurement. The contribution of surface tracer such as $\mathrm{CO}$ is suggestive of a concomitant uplift of elevated $\mathrm{SO}_{2}$ or insoluble organic compounds concentrations, potentially participating in the new particle formation event. Twohy et al. (2002) described a similar event although in their case it was observed in the upper troposphere, and fine particle concentrations were much higher.

\subsection{Seasonal variation}

Fig. 7a and b show respectively the seasonal evolution of $\mathrm{N}_{3-70}$ and $\mathrm{N}_{70-200}$ derived from the 5 years of monthly vertical profiles in Novosibirsk (Arshinov and Belan, 2004). Median ultra-fine particle (3-70 nm) concentrations range between $\sim 300 \mathrm{~cm}^{-3}$ in summer and $30 \mathrm{~cm}^{-3}$ in winter. Fine particles $(70-200 \mathrm{~nm})$ range between 10 and $30 \mathrm{~cm}^{-3}$ in winter and summer, respectively. Variability of ultra-fine particles is higher in June and July, suggesting a shorter lifetime (Williams et al., 2002). The most important feature of Fig. 7 is the difference in concentration between the BL and the FT. The BL height seasonal variation is clearly visible in the data, except for an apparent drop in particle concentration between June and August. The concentrations are maximal in May and September (with both $\mathrm{N}_{3-70}$ and $\mathrm{N}_{70-200}>500 \mathrm{~cm}^{-3}$ ). Kulmala et al. (2004) and Lyubovtseva et al. (2005) observed spring and autumn maxima in nucleation events frequency at the Hyytiälä station in Finland.

Our data do not allow explanation of the summer drop in BL particle concentrations. In summer, conditions typically include a high BL top, higher biogenic precursors emissions (Lathière et al., 2006) and higher growth rates of ion clusters and ultra-fine particles (Hirsikko et al., 2005). In Siberia the months of June, July and August account for $50-60 \%$ of the annual precipitation (Soja et al., 2004), leading to scavenging in the lower troposphere, and are also the period for highest evapo-transpiration. Lower fine particle concentrations in summer could additionally be influenced by the presence of coarser carbonaceous particle from forest fires (Soja et al., 2004), which could increase the condensational sink.

In the free troposphere there is a significant maximum of ultrafine particles in July and August, which could be in situ formation. 

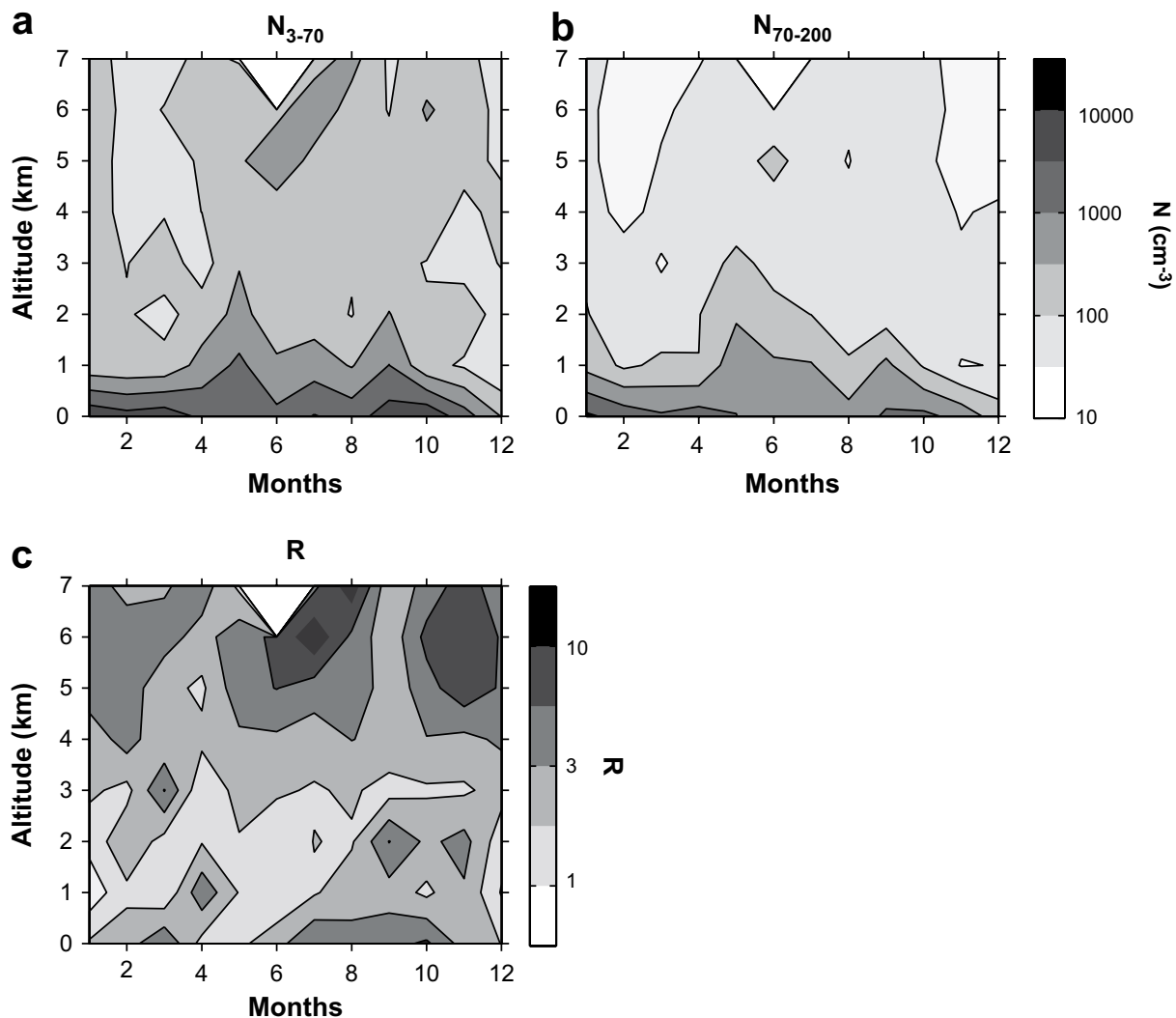

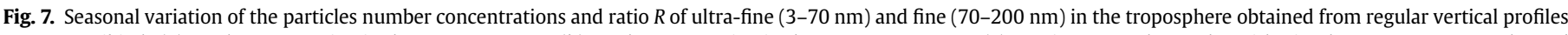

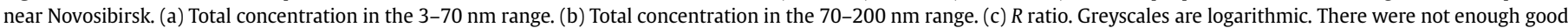
data in June at $7 \mathrm{~km}$ to provide a robust value.

Fig. 7c shows the seasonal and vertical distribution of the $R$ ratio. The FT median size ratio $R$ shows a large variability from 0.1 to 10 , possibly reflecting sporadic fresh particle nucleation. This ratio is maximum in July between 5 and $7 \mathrm{~km}$ altitude ( $R$ inter-quartile range being here 4-12), which suggest summer maximum in situ particle formation, despite wet scavenging by widespread continental convection. A secondary maximum occurs in November, whose origin is unclear. At $5 \mathrm{~km}$ there is a minimum in the $R$ ratio in April, which could be compared to our case study of Asian pollutant export to Siberia during dust storms outbreak (Paris et al., 2008). This minimum is therefore possibly explained by an increased condensational sink preventing new particle formation.

Our September case study identified that uplift of BL air by convection in the mid troposphere and UT/LS conditions can enhance ultra-fine particle concentrations in the FT. These conclusions could explain the summer maximum in the $R$ ratio at $5-7 \mathrm{~km}$ altitude. Alternatively, this finding could also be explained by the hypothesis by Kulmala et al. (2006b) that deep convection of water-insoluble trace gases to the FT are a possible in situ nucleation source in the absence of sulphuric acid.

\section{Summary and conclusions}

Fine $(7-200 \mathrm{~nm})$ particle number concentration measurement during two intensive airborne campaigns in the troposphere above Siberia between Novosibirsk and Yakutsk (the YAK-AEROSIB project) and monthly vertical profiles near Novosibirsk have been presented. During the campaigns, low concentrations on the order of $200 \mathrm{~cm}^{-3}$ have been observed in the free troposphere (FT). Our data are consistent with a possibly widespread gas-to-particle conversion in the free troposphere. In April, no strong excess of fine particles was found in a filament of polluted air originating from NE China, suggesting a dominant effect of condensational sink.

In September 2006, particle concentrations decreased with altitude to reach $\sim 50-200 \mathrm{~cm}^{-3}$ at $7 \mathrm{~km}$. $\mathrm{N}_{70-200}$ exhibited a gradient steeper than that of $\mathrm{N}_{3-70}$. $\mathrm{N}_{3-70}$ accounts for $90 \%$ of the total particle concentration in the free troposphere at $6-7 \mathrm{~km}$ altitude. Two cases of possible nucleation with relatively high concentrations $\left(\sim 200 \mathrm{~cm}^{-3}\right)$ and $\mathrm{N}_{3-70} / \mathrm{N}_{70-200}$ ratios are reported for the September campaign, in the upper troposphere and in cloud outflow in the mid-troposphere. The latter case led to concentrations of $\sim 4000 \mathrm{~cm}^{-3}$ in association with surface emissions as denoted by elevated CO concentrations.

In the seasonal analysis, we found high concentrations $\left(>1000 \mathrm{~cm}^{-3}\right.$ ) and $\mathrm{N}_{3-70} / \mathrm{N}_{70-200}$ ratios in summer in the mid- and upper troposphere, consistent with in situ nucleation. This could be related to either one of the two processes described by our case studies. The summer precipitation maximum, and the high altitude of this maximum could also support the Kulmala et al. (2006b) hypothesis of in situ FT nucleation from water-insoluble precursors. Maximum concentrations in the BL are observed in spring and autumn.

Our aircraft was not equipped to provide high-resolution size distribution or precursors' concentration measurements. Therefore our preliminary results strongly suggest, but cannot diagnose unambiguously, fresh nucleation. Instead, this calls for new, targeted investigation in the clean, continental air shed above Siberia.

\section{Acknowledgements}

The flights crews and Russian-French science teams are thanked for their efforts. Jean-Luc Teffo, Patrick Le Fort, Igor G. Granberg and 
G.G. Golitsyn provided long-lasting support to the project. François Dulac, Markku Kulmala and Jean Sciare provided helpful comments on an earlier version of the manuscript. We thank the reviewers for stimulating comments. Thanks to Andreas Stohl for running the FLEXPART model and making results available. The present work is funded by CNRS, CEA, the French Ministry of Research, the French Ministry of Foreign Affairs (YAK-AEROSIB project) and by RFBR (grants 07-05-00645, 08-05-10033 and 08-05-92499) and RAS.

\section{References}

Ankilov, A., Baklanov, A., Colhoun, M., Enderle, K.H., Gras, J., Julanov, Y., Kaller, D., Lindner, A., Lushnikov, A.A., Mavliev, R., McGovern, F., O'Connor, T.C., Podzimek, J., Preining, O., Reischl, G.P., Rudolf, R., Sem, G.J., Szymanski, W.W., Vrtala, A.E., Wagner, P.E., Winklmayr, W., Zagaynov, V., 2002a. Particle size dependent response of aerosol counters. Atmospheric Research 62, 209-237.

Ankilov, A., Baklanov, A., Colhoun, M., Enderle, K.H., Gras, J., Julanov, Y., Kaller, D., Lindner, A., Lushnikov, A.A., Mavliev, R., McGovern, F., Mirme, A., O’Connor, T.C., Podzimek, J., Preining, O., Reischl, G.P., Rudolf, R., Sem, G.J., Szymanski, W.W., Tamm, E., Vrtala, A.E., Wagner, P.E., Winklmayr, W., Zagaynov, V., 2002b. Intercomparison of number concentration measurements by various aerosol particle counters. Atmospheric Research 62, 177-207.

Arshinov, M.Yu., Belan, B.D., 2004. Vertical distribution of nanoparticles in the continental troposphere. Atmospheric and Oceanic Optics 17 (7), 489-499.

Arshinov, M.Yu., Belan, B.D., Nedelec, Ph., Paris, J.-D., Machida, T., 2007. Spatial distribution of nanoparticles in the free troposphere over Siberia. In:. O'Dowd, C.D., Wagner, P.E. (Eds.), Nucleation and Atmospheric Physics, 17th International Conference on Nucleation and Atmospheric Aerosols, Galway, Ireland, 2007. Springer, New York, pp. 819-823.

Baldocchi, D., Kelliher, F.M., Black, T.A., Jarvis, P., 2000. Climate and vegetation controls on boreal zone energy exchange. Global Change Biology 6, 69-83.

Bashurova, V.S., Dreiling, V., Hodger, T.V., Jaenicke, R., Koutsenogii, K.P. Koutsenogii, P.K., Kraemer, M., Makarov, V.I., Obolkin, V.A., Potjomkin, V.L., Pusep, A.Y., 1992. Measurements of atmospheric condensation nuclei size distributions in Siberia. Journal of Aerosol Science 23, 191-199.

Benson, D.R., Young, L.H., Lee, S.H., Campos, T.L., Rogers, D.C., Jensen, J., 2008. The effects of airmass history on new particle formation in the free troposphere: case studies. Atmospheric Chemistry and Physics 8 (12), 3015-3024.

Buzorius, G., McNaughton, C.S., Clarke, A.D., Covert, D.S., Blomquist, B., Nielsen, K. Brechtel, F.J., 2004. Secondary aerosol formation in continental outflow conditions during ACE-Asia, Journal of Geophysical Research 109, D24203. doi: 10.1029/2004JD004749.

Charlson, R.J.. Langner,J., Rodhe, H., 1990. Sulfate Aerosol and Climate. Nature 348, 22-22.

Clarke, A.D., Varner, J.L., Eisele, F., Mauldin, R.L., Tanner, D., Litchy, M., 1998. Particle production in the remote marine atmosphere: Cloud outflow and subsidence during ACE 1. Journal of Geophysical Research 103, 16397-16409.

Clarke, A.D., Eisele, F., Kapustin, V.N., Moore, K., Tanner, D., Mauldin, L., Litchy, M., Lienert, B., Carroll, M.A., Albercook, G., 1999. Nucleation in the equatorial free troposphere: Favorable environments during PEM-Tropics. Journal of Geophysical Research 104, 5735-5744.

Covert, D.S., Kapustin, V.N., Quinn, P.K., Bates, T.S., 1992. New particle formation in the marine boundary layer. Journal of Geophysical Research 97 (18), 20581-29589.

Dal Maso, M., Sogacheva, L., Anisimov, M.P., Arshinov, M., Baklanov, A., Belan, B. Khodzher, T.V., Obolkin, V.A., Staroverova, A., Vlasov, A., Zagaynov, V.A Lushnikov, A., Lyubovtseva, Y.S., Riipinen, I., Kerminen, V.M., Kulmala, M., 2008. Aerosol particle formation events at two Siberian stations inside the boreal forest. Boreal Environment Research 13, 81-92.

Heintzenberg, J., Birmili, W., Theiss, D., Kisilyakhov, Y., 2008. The atmospheric aerosol over Siberia, as seen from the $300 \mathrm{~m}$ ZOTTO tower. Tellus 60B, 276-285.

Hermann, M., Heintzenberg, J., Wiedensohler, A., Zahn, A., Heinrich, G., Brenninkmeijer, C.A.M., 2003. Meridional distributions of aerosol particle number concentrations in the upper troposphere and lower stratosphere obtained by Civil Aircraft for Regular Investigation of the Atmosphere Based on an Instrument Container (CARIBIC) flights. Journal of Geophysical Research 108 (D3).

Hoppel, W.A., Frick, G.M., Fitzgerald, J., Larson, R.E., 1994. Marine boundary-laye measurements of new particle formation and the effects nonprecipitating clouds have on aerosol-size distribution. Journal of Geophysical Research 99 (D7), 14443-14459.

Korhonen, P., Kulmala, M., Laaksonen, A., Viisanen, Y., McGraw, R., Seinfeld, J.H., 1999. Ternary nucleation of $\mathrm{H}_{2} \mathrm{SO}_{4}, \mathrm{NH}_{3}$, and $\mathrm{H}_{2} \mathrm{O}$ in the atmosphere. Journal of Geophysical Research 104 (D21), 26349-26353.

Koutsenogii, P., 1997. Aerosol measurements in Siberia. Atmospheric Research 44 167-173.

Koutsenogii, P.K., Bufetov, N.S., Drozdova, V.I., Golobkova, V.L., Khodger, T.V Koutzenogii, K.P. Makarov, V.I., Obolkin, V.A., Potemkin, V.L, 1993. Ion Composition of Atmospheric Aerosol near Lake Baikal. Atmospheric Environment 27,1629-1633.

Kulmala, M., Vehkamaki, H., Petaja, T., Dal Maso, M., Lauri, A., Kerminen, V.M. Birmili, W., McMurry, P.H., 2004. Formation and growth rates of ultrafine atmospheric particles: a review of observations. Journal of Aerosol Science 35,143-176.

Kulmala, M., Lehtinen, K.E.J., Laaksonen, A., 2006a. Cluster activation theory as an explanation of the linear dependence between formation rate of $3 \mathrm{~nm}$ particles and sulphuric acid concentration. Atmospheric Chemistry and Physics 6, 787-793.

Kulmala, M., Reissell, A., Sipila, M., Bonn, B., Ruuskanen, T.M., Lehtinen, K.E.J., Kerminen, V.M., Strom, J., 2006b. Deep convective clouds as aerosol production engines: Role of insoluble organics. Journal of Geophysical Research 111 (D17), D17202. doi:10.1029/2005JD006963.

Lathiere, J., Hauglustaine, D.A., Friend, A.D., De Noblet-Ducoudre, N., Viovy, N., Folberth, G.A., 2006. Impact of climate variability and land use changes on global biogenic volatile organic compound emissions. Atmospheric Chemistry and Physics 6, 2129-2146.

Leaitch, W.R., Isaac, G.A., 1991. Tropospheric Aerosol Size Distributions from 1982 to 1988 over Eastern North-America. Atmospheric Environment 25A(3-4), 601-619.

Lee, S.-H., Reeves, J.M., Wilson, J.C., Hunton, D.E., Viggiano, A.A., Miller, T.M. Ballenthin, J.O., Lait, L.R., 2003. Particle formation by ion nucleation in the upper troposphere and lower stratosphere. Science 301, 1886-1889.

Lin, C.Y., Wang, Z., Chen, W.N., Chang, S.Y., Chou, C.C.K., Sugimoto, N., Zhao, X., 2007. Long-range transport of Asian dust and air pollutants to Taiwan: observed evidence and model simulation. Atmospheric Chemistry and Physics 7, 423-434.

Minikin, A., Petzold, A., Strom, J., Krejci, R., Seifert, M., van Velthoven, P., Schlager, H., Schumann, U., 2003. Aircraft observations of the upper tropospheric fine particle aerosol in the Northern and Southern Hemispheres at midlatitudes. Geophysical Research Letters 30 (10).

Nedelec, P., Cammas, J.P., Thouret, V., Athier, G., Cousin, J.M., Legrand, C., Abonnel, C., Lecoeur, F., Cayez, G., Marizy, C., 2003. An improved infrared carbon monoxide analyser for routine measurements aboard commercial Airbus aircraft: technical validation and first scientific results of the MOZAIC III programme. Atmospheric Chemistry and Physics 3, 1551-1564.

Nyeki, S., Kalberer, M., Lugauer, M., Weingartner, E., Petzold, A., Schroder, F., Colbeck, I., Baltensperger, U., 1999. Condensation Nuclei (CN) and Ultrafine CN in the Free Troposphere to $12 \mathrm{~km}$ : A case study over the Jungfraujoch highalpine research station. Geophysical Research Letters 26, 2195-2198.

O’Dowd, C.D., Aalto, P., Hameri, K., Kulmala, M., Hoffmann, T., 2002. Aerosol formation - Atmospheric particles from organic vapours. Nature 416 (6880), 497-498.

Ohara, T., Akimoto, H., Kurokawa, J., Horii, N., Yamaji, K., Yan, X., Hayasaka, T., 2007. An Asian emission inventory of anthropogenic emission sources for the period 1980-2020. Atmospheric Chemistry and Physics 7, 4419-4444.

Paris, J.-D., Ciais, P., Nédélec, P., Ramonet, M., Belan, B.D., Arshinov, M.Yu., Golitsyn, G.S., Granberg, I., Stohl, A., Cayez, G., Athier, G., Boumard, F., Cousin, J.M., 2008. The YAK-AEROSIB transcontinental aircraft campaigns: new insights on the transport of $\mathrm{CO}_{2}, \mathrm{CO}$ and $\mathrm{O}_{3}$ across Siberia. Tellus 60B (4), 551-568.

Reischl, G.P., Majerowicz, A., Ankilow, A., Eremenko, S., Mavliev, R., 1991. Comparison of the Novosibirsk automated diffusion battery with the Vienna electro mobility spectrometer. Journal of Aerosol Science 22, 223-228.

de Reus, M., Strom, J., Curtius, J., Pirjola, L., Vignati, E., Arnold, F., Hansson, H.C., Kulmala, M., Lelieveld, J., Raes, F., 2000. Aerosol production and growth in the upper free troposphere. Journal of Geophysical Research 105, 24751-24762.

Schröder, F., Ström, J., 1997. Aircraft measurements of sub micrometer aerosol particles $(>7 \mathrm{~nm})$ in the midlatitude free troposphere and tropopause region. Atmospheric Research 44 (3-4), 333-356.

Seinfeld, J.H., Pandis, S.N., 1998. Atmospheric Chemistry and Physics: From Air Pollution to Climate Change. Wiley, New York, 1326 pp.

Soja, A.J., Cofer, W.R., Shugart, H.H., Sukhinin, A.I., Stackhouse, P.W., McRae, D.J., Conard, S.G., 2004. Estimating fire emissions and disparities in boreal Siberia (1998-2002). Journal of Geophysical Research, 109.

Stohl, A., Forster, C., Frank, A., Seibert, P., Wotawa, G., 2005. Technical note: The Lagrangian particle dispersion model FLEXPART version 6.2. Atmospheric Chemistry and Physics 5, 2461-2474.

Stull, R.B., 1988. Introduction to Boundary-Layer Meteorology. Kluwer Academic Publishers, Dordrecht, 666 pp.

Tarvainen, V., Hakola, H., Rinne, J., Hellen, H., Haapanala, S., 2007. Towards a comprehensive emission inventory of terpenoids from boreal ecosystems. Tellus B 59 (3), 526-534.

Twohy, C.H., Clement, C.F., Gundrud, B.W., Weinheimer, A.J., Campos, T.L., Baumgardner, D., Brune, W.B., Faloona, I., Sachse, G.W., Vay, S.A., Tan, D., 2002. Deep convection as a source of new particles in the midlatitude upper troposphere, Journal of Geophysical Research, 107. doi:10.1029/2001JD000323.

Vartiainen, E., Kulmala, M., Ehn, M., Hirsikko, A., Junninen, H., Petaja, T., Sogacheva, L., Kuokka, S., Hillamo, R., Skorokhod, A., Belikov, I., Elansky, N., Kerminen, V.M., 2007. Ion and particle number concentrations and size distributions along the Trans-Siberian railroad. Boreal Environment Research 12, 375-396.

Weber, R.J., Marti, J.J., McMurry, P.H., Eisele, F.L., Tanner, D.J., Jefferson, A., 1996 Measured atmospheric new particle formation rates: implications for nucleation mechanisms. Chemical Engineering Communications 151, 53-64.

Williams, J., de Reus, M., Krejci, R., Fischer, H., Strom, J., 2002. Application of the variability-size relationship to atmospheric aerosol studies: estimating aerosol lifetimes and ages. Atmospheric Chemistry and Physics 2, 133-145.

Young, L.H., Benson, D.R., Montanaro, W.M., Lee, S.H., Pan, L.L., Rogers, D.C., Jensen, J., Stith, J.L, Davis, C.A. Campos, T.L., Bowman, K.P., Cooper, W.A., Lait, L.R, 2007. Enhanced new particle formation observed in the northern midlatitude tropopause region. Journal of Geophysical Research 112.

Zuev, V.E., Belan, B.D., Kabanov, D.M., Kovalevskii, V.K., Luk'ianov, O.Iu., Meleshkin, V.E., Mikushev, M.K., Panchenko, M.V., Penner, I.E., Pokrovskii, E.V., 1992. The Optik-E AN-30 laboratory-airplane for ecological studies. Atmospheric and Oceanic Optics 5, 1012-1021. 